\title{
Changes in Morphological Characteristics During the Period 2005 - 2014 in a Sample of Serbian 7 - Year-Old Children
}

\author{
Cambios en las Características Morfológicas Durante el Período 2005 - 2014 \\ en una Muestra de Niños Serbios de 7 Años de Edad
}

Tatjana Pavlica; Rada Rakic \& Tijana Sironjic

PAVLICA, T.; RAKIC, R. \& SIRONJIC, T. Changes in morphological characteristics during the period 2005 - 2014 in a sample of Serbian 7- year-old children. Int. J. Morphol., 35(2):691-697, 2017.

SUMMARY: Morphological characteristics of children commonly imply the processes of growth and development. Information on children's growth in height and their body weight is often used as the indicator of the children's health and nutritional status. As the parameters are changeable both temporally and spatially, it is important to provide their continual assessment. The aim of the study is to investigate the changes in morphological characteristics in a sample of Serbian 7-year-old children in the period 2005 - 2014. The data was gathered from medical documentation recorded in the period 2005-2014 in the local health-care centre "Dr Dusan Savic- Doda" in Beocin, which is situated in the central part of the province Vojvodina, the north-west part of Serbia. Most of the population consists of Serbs $(69.7 \%)$, and the second largest group are Roma (9\%) who came to this region in the 1990s as refugees from Kosovo. The categorization of the participants was based on their decimal age ranging from 6.50 to 7.49 years. Body height and weight were measured, and nutritional status categories were set in relation to the cut off values of body mass index (BMI) of the age of $7\left(\mathrm{~kg} / \mathrm{m}^{2}\right)$ as proposed by IOTF- International Obesity Task Force. The study has pointed to an increasing trend in height and a decrease of BMI. Analysing the period of ten years, the height, weight and BMI in seven-year-olds living on the territory on Beocin municipality have proven to be slightly lower than in the children of the same age in other parts of Vojvodina and Serbia. The obtained results point to the need of further investigations of children living in this region in order to provide a better insight into the changes of the morphological parameters.

KEY WORDS: Height; Weight; BMI; Secular trend; Serbia.

\section{INTRODUCTION}

Morphological parameters are good indicators of children and adolescents' growth and development and physical appearance and constitution of adults. Morphological traits are affected by a number of endogenic and exogenic factors. Each stage of ontogenesis is marked by specific reference values of morphological parameters. Monitoring of growth and development is based on the assessment of morphological parameters which enables us to compare generations living in different periods. As the parameters are changeable both temporally and spatially, it is important to provide their continual assessment.

The height is considered to be the best and most stable indicator of growth, maturation and bone mass development. It is therefore an important indicator of longitudinal dimensionality of the skeleton. The weight is affected by the development of tissues and considerably varies during growth and maturation. The adequate weight is one of the most interesting aspects of development and is closely related to both physical and motor development (Podstawski \& Borysawski, 2012). Anthropometric parameters are also important in assessing children's motor skills (Ceylan et al., 2014).

The twentieth century brought rapid physical growth, particularly in the population of developed countries (Cole, 2003). The height value increased by $1 \mathrm{~cm}$ per decade and there was an increase in other body dimensions in population of all ages. The phenomenon has been defined as the secular trend or growth acceleration. The secular trend represents a natural experiment reflecting a complex interaction of genes, physiology and the environment and all of these factors define the body shape and size of a generation to generation (Cole, 2003). The study of the secular trend is one of the most widely researched areas in the domain of physical anthropology. Since 1990 numerous studies have 
reported a relative increase in various body segments (Kromeyer-Hauschild \& Jaeger, 2000) and earlier entering into puberty, i.e. a progressively earlier appearance of secondary sexual characteristics in boys and girls (HermanGiddens, 2006; Kaplowitz, 2006). The rate of secular changes in body height has varied in relation to the age and living conditions. Nevertheless, weight changes are not always proportional to the changes in height.

The secular trend has been decreasing in most of the developed countries and those characterized by high living standards. This implies that stable conditions in optimum living standards of regular nutrition, housing, etc. allow the gene potential of growth to be fully developed. These changes have been recorded in all social groups in Europe, the USA and Japan, but they are not universal in populations. In the population of underdeveloped areas of Asia, Africa and Latin America the acceleration is hardly observable. In some populations there is even the negative secular trend recorded. Poor living conditions, wars, post-war period and poverty have a negative impact on acceleration.
Serbia is a country that has faced dramatic political and economic changes in last few decades. In early 1990 there was a war at the territory of former Yugoslavia which resulted in a vast number of refugees coming to Serbia and causing significant demographic and socio-economic changes. The changes in morphological traits have mostly been monitored in cities and as for rural areas, the monitoring has been sporadic. The aim of the present study is to investigate the changes in height, weight and nutritional status using BMI in 7-year-old children from rural areas in the municipality of Beocin, the north-west part of Serbia.

\section{MATERIAL AND METHOD}

Regular medical checkups of seven-year-old pupils in the municipality of Beocin served as a data base on morphological characteristics. The data was gathered from medical documentation recorded in the period 2005-2014

Table I. The height of seven-year-olds in the period 2005/2014

\begin{tabular}{|c|c|c|c|c|c|c|}
\hline \multirow[b]{2}{*}{ Sex } & \multirow[b]{2}{*}{ Year } & \multirow[b]{2}{*}{$\mathrm{N}$} & \multirow[b]{2}{*}{ Mean } & \multicolumn{2}{|c|}{$95 \%$ IP } & \multirow[b]{2}{*}{ Increase } \\
\hline & & & & LL & UL & \\
\hline \multirow[t]{13}{*}{ Boys } & 2005 & 52 & 123.01 & 121.49 & 124.53 & \\
\hline & 2006 & 59 & 122.07 & 120.48 & 123.65 & -0.95 \\
\hline & 2007 & 52 & 124.09 & 122.23 & 125.94 & 2.02 \\
\hline & 2008 & 65 & 122.05 & 120.80 & 123.31 & -2.03 \\
\hline & 2009 & 64 & 123.52 & 122.03 & 125.00 & 1.46 \\
\hline & 2010 & 68 & 123.43 & 121.79 & 125.08 & -0.08 \\
\hline & 2011 & 64 & 123.80 & 122.56 & 125.03 & 0.36 \\
\hline & 2012 & 79 & 125.32 & 124.19 & 126.45 & 1.52 \\
\hline & 2013 & 69 & 124.62 & 123.11 & 126.12 & -0.70 \\
\hline & 2014 & 71 & 125.63 & 124.20 & 127.07 & 1.02 \\
\hline & $2005-2009$ & 292 & 122.91 & 122.24 & 123.58 & \\
\hline & $2010-2014$ & 351 & 124.60 & 123.98 & 125.22 & $1.69 * * *$ \\
\hline & Total ${ }^{\ddagger}$ & 643 & 123.83 & 123.37 & 124.29 & $2.62^{* *}$ \\
\hline \multirow[t]{13}{*}{ Girls } & 2005 & 64 & 119.91 & 118.14 & 121.68 & \\
\hline & 2006 & 49 & 122.27 & 120.75 & 123.78 & $2.36^{*}$ \\
\hline & 2007 & 72 & 121.38 & 119.93 & 122.83 & -0.88 \\
\hline & 2008 & 75 & 120.85 & 119.68 & 122.03 & -0.53 \\
\hline & 2009 & 69 & 120.99 & 119.29 & 122.70 & 0.14 \\
\hline & 2010 & 75 & 122.46 & 121.11 & 123.80 & 1.46 \\
\hline & 2011 & 48 & 123.27 & 121.64 & 124.90 & 0.81 \\
\hline & 2012 & 71 & 125.20 & 123.92 & 126.47 & 1.93 \\
\hline & 2013 & 56 & 122.38 & 120.61 & 124.14 & $-2.82 * *$ \\
\hline & 2014 & 70 & 123.34 & 121.81 & 124.86 & 0.96 \\
\hline & $2005-2009$ & 329 & 121.02 & 120.35 & 121.70 & \\
\hline & $2010-2014$ & 320 & 123.36 & 122.70 & 124.03 & $2.34 * * *$ \\
\hline & Total ${ }^{*}$ & 649 & 122.18 & 121.70 & 122.66 & $3.43^{* *}$ \\
\hline
\end{tabular}


in the local health-care centre "Dr Dusan Savic - Doda" in Beocin. The municipality of Beocin is situated in the central part of the province Vojvodina, the north-west part of Serbia. According to the 2011 Census, the population of Beocin municipality consists of 15,726 people living in 5,577 households. There are 8 rural settlements of the average area of $23.3 \mathrm{~km}^{2}$. Most of the population consists of Serbs $(69.7 \%)$, and the second largest group are Roma (9 $\%$ ) who came to this region in the 1990 as refugees from Kosovo. Other ethnic groups, about 20 of them, are present in very small percentages. The survey included 881 children, 440 girls and 441 boys, all of them being Serbs $(74.76 \%)$ and Roma (25.23\%). The categorization of the participants was based on their decimal age ranging from 6.50 to 7.49 years. Mechanical weighing scale (SE 709) was used for measuring weight and height. The nutritional status categories were set in relation to the cut off values of body mass index (BMI) of the age of $7\left(\mathrm{~kg} / \mathrm{m}^{2}\right)$ as proposed by IOTF- International Obesity Task Force (Cole, 2000). The data processing included calculation of means and a $95 \%$ confidence interval for height, weight and BMI.

Table II. The weight of seven-year-olds in the period 2005-2014.

\begin{tabular}{|c|c|c|c|c|c|c|}
\hline \multirow[b]{2}{*}{ Sex } & \multirow[b]{2}{*}{ Year } & \multirow[b]{2}{*}{$\mathrm{N}$} & \multirow[b]{2}{*}{ Mean } & \multicolumn{3}{|c|}{$95 \%$ IP } \\
\hline & & & & $\mathrm{LL}$ & UL & Increase \\
\hline \multirow[t]{13}{*}{ Boys } & 2005 & 52 & 24.81 & 23.55 & 26.07 & \\
\hline & 2006 & 59 & 23.33 & 22.15 & 24.51 & -1.48 \\
\hline & 2007 & 52 & 24.25 & 22.86 & 25.64 & 0.92 \\
\hline & 2008 & 65 & 24.48 & 23.20 & 25.77 & 0.23 \\
\hline & 2009 & 64 & 24.13 & 23.02 & 25.24 & -0.35 \\
\hline & 2010 & 68 & 24.08 & 22.68 & 25.48 & -0.05 \\
\hline & 2011 & 64 & 24.22 & 23.28 & 25.17 & 0.14 \\
\hline & 2012 & 79 & 24.11 & 23.07 & 25.15 & -0.11 \\
\hline & 2013 & 69 & 24.41 & 23.17 & 25.64 & 0.29 \\
\hline & 2014 & 71 & 24.31 & 23.22 & 25.40 & -0.10 \\
\hline & $2005-2009$ & 292 & 24.19 & 23.64 & 24.74 & \\
\hline & $2010-2014$ & 351 & 24.22 & 23.72 & 24.73 & 0.03 \\
\hline & Total $^{*}$ & 643 & 24.21 & 23.84 & 24.58 & -0.50 \\
\hline \multirow[t]{13}{*}{ Girls } & 2005 & 64 & 22.56 & 21.43 & 23.69 & \\
\hline & 2006 & 49 & 23.26 & 21.98 & 24.53 & 0.69 \\
\hline & 2007 & 72 & 23.15 & 22.27 & 24.04 & -0.10 \\
\hline & 2008 & 75 & 23.04 & 22.09 & 23.99 & -0.11 \\
\hline & 2009 & 69 & 23.42 & 22.22 & 24.63 & 0.38 \\
\hline & 2010 & 75 & 22.14 & 21.01 & 23.27 & -1.28 \\
\hline & 2011 & 48 & 23.80 & 22.79 & 24.82 & $1.66^{*}$ \\
\hline & 2012 & 71 & 23.07 & 22.01 & 24.14 & -0.73 \\
\hline & 2013 & 56 & 23.31 & 21.87 & 24.75 & 0.24 \\
\hline & 2014 & 70 & 22.59 & 21.47 & 23.71 & -0.72 \\
\hline & $2005-2009$ & 329 & 23.08 & 22.61 & 23.56 & \\
\hline & $2010-2014$ & 320 & 22.90 & 22.39 & 23.41 & -0.18 \\
\hline & Total ${ }^{*}$ & 649 & 22.99 & 22.64 & 23.34 & 0.03 \\
\hline
\end{tabular}

\$-Difference between 2014 and 2005; * - difference between the current and preceding year or period; †- t-test; *p<0,05; CI- Confidence Interval; LL- Lower limit; UL- Upper limit
T-test was used for determining the differences in the samples and the Chi-Square test $\left(\chi^{2}\right)$ was applied for assessing the differences in nutritional status categories.

The study was approved by the Council of Department of Biology and Ecology and by manager of health-care centre "Dr Dusan Savic - Doda" in Beocin.

\section{RESULTS}

As for boys, no significant increase or decrease in height is recorded when the years of investigation are analysed successively (Table I), while in girls a significant increase of $2.36 \mathrm{~cm}$ is observed in the period 2005-2006 $(\mathrm{p}<0.05)$, and in the period 2012-2013 there is a decrease of $-2.82 \mathrm{~cm}(\mathrm{p}<0.01)$. In both boys and girls statistically significant difference is observable between the values recorded in $2005(123.01,119.91 \mathrm{~cm})$ and $2014(125.63$, $123.34 \mathrm{~cm})$. These results point to a significant increase in height in the 10-year-long period, in boys the increase of $2.62 \mathrm{~cm}(t=-2.468$; $\mathrm{p}=0.014)$, and in girls the increase of $3.43 \mathrm{~cm}(t=-2.941 ; \mathrm{p}=0.004)$.

The weight values (Table II) generally show no significant differences when the years are compared successively. The only exception to this is the period 20102011 as a significant increase is detected in girls $(\mathrm{p}<0.05)$. No significant differences are recorded between the first (2005) and the last year (2014) of survey, which points to a stagnation in this morphological trait of 7-year-old children.

As for BMI (Table III), boys show no significant differences in the successive years. The situation is somewhat different in girls, as some differences are noticable in different years of investigation. In both boys and girls significant differences can be observed between the years 2005 and $2014\left(16.33,15.58 \mathrm{~kg} / \mathrm{m}^{2}\right.$ and 15.29 , $14.74 \mathrm{~kg} / \mathrm{m}^{2}$, respectively). This result points to a considerable decrease of BMI during the period of 10 years ($1.04 \mathrm{~kg} / \mathrm{m}^{2}(\mathrm{p}<0.05)$ in boys, and -0.85 $\mathrm{kg} / \mathrm{m}^{2}(\mathrm{p}<0.05)$ in girls $)$. 
Table III. BMI of seven-year-olds in the period 2005-2014.

\begin{tabular}{|c|c|c|c|c|c|c|}
\hline \multirow[b]{2}{*}{ Sex } & \multirow[b]{2}{*}{ Year } & \multirow[b]{2}{*}{$\mathrm{N}$} & \multicolumn{4}{|c|}{$95 \%$ IP } \\
\hline & & & Mean & LL & UL & Increase \\
\hline \multirow[t]{13}{*}{ Boys } & 2005 & 52 & 16.33 & 15.68 & 16.97 & \\
\hline & 2006 & 59 & 15.55 & 15.03 & 16.06 & -0.78 \\
\hline & 2007 & 52 & 15.61 & 15.05 & 16.17 & 0.06 \\
\hline & 2008 & 65 & 16.32 & 15.67 & 16.96 & 0.71 \\
\hline & 2009 & 64 & 15.71 & 15.27 & 16.16 & -0.60 \\
\hline & 2010 & 68 & 15.66 & 15.00 & 16.33 & -0.05 \\
\hline & 2011 & 64 & 15.75 & 15.28 & 16.23 & 0.09 \\
\hline & 2012 & 79 & 15.28 & 14.77 & 15.78 & -0.48 \\
\hline & 2013 & 69 & 15.59 & 15.07 & 16.11 & 0.31 \\
\hline & 2014 & 71 & 15.29 & 14.82 & 15.75 & -0.30 \\
\hline & $2005-2009$ & 292 & 15.91 & 15.66 & 16.16 & \\
\hline & $2010-2014$ & 351 & 15.50 & 15.27 & 15.74 & -0.40 \\
\hline & Total $^{\ddagger}$ & 643 & 15.69 & 15.51 & 15.86 & $-1.04 *$ \\
\hline \multirow[t]{13}{*}{ Girls } & 2005 & 64 & 15.58 & 15.04 & 16.13 & \\
\hline & 2006 & 49 & 15.48 & 14.82 & 16.14 & -0.10 \\
\hline & 2007 & 72 & 15.66 & 15.22 & 16.10 & 0.18 \\
\hline & 2008 & 75 & 15.69 & 15.22 & 16.15 & 0.03 \\
\hline & 2009 & 69 & 15.85 & 15.32 & 16.38 & 0.17 \\
\hline & 2010 & 75 & 14.64 & 14.12 & 15.16 & $-1.21 * * *$ \\
\hline & 2011 & 48 & 15.62 & 15.15 & 16.09 & $0.98 * *$ \\
\hline & 2012 & 71 & 14.62 & 14.16 & 15.07 & $-1.00 * *$ \\
\hline & 2013 & 56 & 15.44 & 14.73 & 16.15 & $0.82^{*}$ \\
\hline & 2014 & 70 & 14.74 & 14.23 & 15.24 & 0.70 \\
\hline & 2005-2009 & 329 & 15.66 & 15.44 & 15.89 & \\
\hline & $2010-2014$ & 320 & 14.94 & 14.70 & 15.18 & -0.72 \\
\hline & Total $^{*}$ & 649 & 15.31 & 15.14 & 15.48 & $-0.85^{*}$ \\
\hline
\end{tabular}

\$-Difference between 2014 and 2005; * - difference between the current and preceding year or period; $* \mathrm{p}<0.05 ; * * \mathrm{p}<0.01 ; * * * \mathrm{p}<0.001$; CI- Confidence Interval; LL- Lower limit; UL- Upper limit

The categories of nutritional status of boys (Table IV) suggest that the largest number of these subjects belong to the category with normal weight values. The category of normal nutritional status is present in $66.2 \%$. The underweight category is more observable than overweight and obesity as $21.3 \%$ of boys are underweight opposed to $7.5 \%$ of overweight and $5 \%$ of obese boys. The prevalence of underweight is generally observable when the years of survey are analysed. In the first 5 years (the period 2005-2009) the underweight prevalence equals $16.42 \%$, and in the next five-year period it increases to $25.42 \%$, thus pointing to the difference of $9 \%$ which proves to be statistically significant $\left(\chi^{2}=4,155\right.$; $\mathrm{p}<0,05)$. As for the prevalence of overweight and obesity, no significant changes are detected in the ten-year period.

When the girls nutritional status is analysed (Table V), $60 \%$ of them are with normal weight, $25 \%$ are underweight and the prevalence of overweight and obesity equals $12.7 \%$ and $2.3 \%$, respectively. In comparison with boys, there are no differences concerning the underweight prevalence. The differences, however, appear regarding the overweight and obesity prevalence, with more girls being overweight $\left(\chi^{2}=5.99 ; \mathrm{p}<0.05\right)$ and more boys being obese $\left(\chi^{2}=4.47 ; \mathrm{p}<0.05\right)$. Similar to boys, the underweight prevalence is observable, while the prevalence of overweight and obesity show no significant changes. In the first five years the total number of underweight girls equals $18.15 \%$, and in the following five years it raises to $31.82 \%$, which represents a difference of $13.67 \%\left(\chi^{2}=8,18 ; p<0,01\right)$.

Table IV. Nutritional status of boys

\begin{tabular}{cccccccccc}
\hline Year & $\mathbf{N}$ & \multicolumn{2}{c}{ Underweight } & \multicolumn{3}{c}{ Normal nutritional status } & \multicolumn{2}{c}{ Overweight } & \multicolumn{2}{c}{ Obesity } \\
& & $\mathrm{n}$ & $\%$ & $\mathrm{n}$ & $\%$ & $\mathrm{n}$ & $\%$ & $\mathrm{n}$ & $\%$ \\
\hline 2005 & 37 & 3 & 8.1 & 29 & 78.4 & 3 & 8.1 & 2 & 5.4 \\
2006 & 46 & 10 & 21.7 & 33 & 71.7 & 1 & 2.2 & 2 & 4.4 \\
2007 & 36 & 7 & 19.4 & 24 & 66.7 & 3 & 8.3 & 2 & 5.6 \\
2008 & 42 & 6 & 14.3 & 26 & 61.9 & 4 & 9.5 & 6 & 14.3 \\
2009 & 40 & 7 & 17.5 & 30 & 75 & 2 & 5 & 1 & 2.5 \\
2010 & 46 & 12 & 26.1 & 26 & 56.5 & 4 & 8.7 & 4 & 8.7 \\
2011 & 42 & 6 & 14.3 & 32 & 76.2 & 4 & 9.5 & $/$ & $/$ \\
2012 & 55 & 17 & 30.9 & 31 & 56.4 & 4 & 7.3 & 3 & 5.4 \\
2013 & 42 & 8 & 19 & 27 & 64.3 & 5 & 11.9 & 2 & 4.8 \\
2014 & 55 & 18 & 32.7 & 34 & 61.8 & 3 & 5.5 & $/$ & $/$ \\
Total & $\mathbf{4 4 1}$ & $\mathbf{9 4}$ & $\mathbf{2 1 . 3}$ & $\mathbf{2 9 2}$ & $\mathbf{6 6 . 2}$ & $\mathbf{3 3}$ & $\mathbf{7 . 5}$ & $\mathbf{2 2}$ & $\mathbf{5}$ \\
\hline
\end{tabular}


Table V. Nutritional status of girls.

\begin{tabular}{|c|c|c|c|c|c|c|c|c|c|}
\hline \multirow[t]{2}{*}{ Year } & \multirow[t]{2}{*}{$\mathrm{N}$} & \multicolumn{2}{|c|}{ Underweight } & \multicolumn{2}{|c|}{$\begin{array}{c}\text { Normal } \\
\text { nutritional status }\end{array}$} & \multicolumn{2}{|c|}{ Overweight } & \multicolumn{2}{|c|}{ Obesity } \\
\hline & & $\mathrm{n}$ & $\%$ & $\mathrm{n}$ & $\%$ & $\mathrm{n}$ & $\%$ & $\mathrm{n}$ & $\%$ \\
\hline 2005 & 45 & 3 & 6.7 & 31 & 68.9 & 9 & 20 & 2 & 4.4 \\
\hline 2006 & 39 & 9 & 23.1 & 25 & 64.1 & 3 & 7.7 & 2 & 5.1 \\
\hline 2007 & 44 & 8 & 18.2 & 34 & 77.3 & 2 & 4.5 & / & / \\
\hline 2008 & 48 & 11 & 22.9 & 33 & 68.8 & 4 & 8.3 & 1 & 1 \\
\hline 2009 & 44 & 9 & 20.5 & 23 & 52.3 & 11 & 25 & 1 & 2.2 \\
\hline 2010 & 41 & 19 & 46.3 & 14 & 34.2 & 7 & 17.1 & 1 & 2.4 \\
\hline 2011 & 36 & 6 & 16.7 & 24 & 66.6 & 6 & 16.7 & l & l \\
\hline 2012 & 51 & 18 & 35.3 & 29 & 56.9 & 3 & 5.9 & 1 & 1.9 \\
\hline 2013 & 36 & 7 & 19.4 & 24 & 66.7 & 4 & 11.1 & 1 & 2.8 \\
\hline 2014 & 56 & 20 & 35.7 & 29 & 51.8 & 5 & 8.9 & 2 & 3.6 \\
\hline Total & 440 & 110 & 25 & 266 & 60 & 56 & 12.7 & 10 & 2.3 \\
\hline
\end{tabular}

\section{DISCUSSION}

A ten-year-long assessment of the height of 7-year-old children living in the municipality of Beocin shows that the average height of boys and girls equals 123.83 and $122.18 \mathrm{~cm}$, respectively. Comparing these results with the data obtained in a large-scale study on 633 seven-year-old children from Vojvodina, North Serbia (Rakic, 2009), where the recorded values were $126.04 \mathrm{~cm}$ (boys) and $124.82 \mathrm{~cm}$ (girls), the children in this study show lower values in height. The values are also significantly lower when compared with the study conducted in the city of Nis, South Serbia, (Djuraskovic et al., 2009), as the recorded means in this city equaled $129.03 \mathrm{~cm}$ in boys and $127.68 \mathrm{~cm}$ in girls. A similar situation is recorded in the town of Jagodina, Central Serbia, (Pavlica et al., 2012), as the reported height ( $127.29 \mathrm{~cm}$ in boys and $126.98 \mathrm{~cm}$ in girls) is higher than in the present study. On international basis, the present results are lower when compared with the data obtained in 7-year-old boys and girls in Turkey (Ceylan et al.), the reported values being 124.61 and $123.30 \mathrm{~cm}$, and in Macedonia, the reported height of 125.14 and $123.8 \mathrm{~cm}$ in boys and girls, respectively (Zafirova \& Todorovska, 2009).

When the data obtained in the first half of the investigation (2005-2009) is compared with that obained in the second half (2010-2014), an increase in the height values is observed. In boys, there is an increase of $1.69 \mathrm{~cm}$ and in girls it is $2.34 \mathrm{~cm}$, which proves to be statistically significant difference. The results point to a secular trend in the height of both boys and girls. Height acceleration has recently been reported in seven-year-olds in the town of Zajecar (Cukic et al., 2012), Vojvodina (Rakic), Nis (Djuraskovic et al.), Italy (Toselli et al., 2006) and Australia (Loesch et al., 2000).

The average weight recorded in this investigation equals $24.21 \mathrm{~kg}$ in boys and $22.99 \mathrm{~kg}$ in girls. The values are lower in comparison with those recorded in other parts of the region of Vojvodina, North Serbia (Rakic), where the reported weight was $27.92 \mathrm{~kg}$ in boys and $26.57 \mathrm{~kg}$ in girls. The same holds good for the results recorded in seven-year-olds in the city of Nis, South Serbia (Djuraskovic et al.), boys $30.26 \mathrm{~kg}$; girls $29.66 \mathrm{~kg}$ and in Jagodina- Central Serbia (Pavlica et al.) - boys $27.43 \mathrm{~kg}$; girls $27.88 \mathrm{~kg}$. The obtained weight values are also lower in comparison with the results reported in Spain (Moreno et al., 2002), Portugal
(Padez et al., 2004), Norway (Holm et al., 2008), and Macedonia (Zafirova \& Todorovska), but they appear to be higher than those in Saudi Arabia (al-Hazzaa, 1990), Egypt (Bharati et al., 2005) and India (Kumar et al., 2004). There are no significant changes in weight during the ten-year long period. The results are not in line with the study conducted in the city of Nis (Pantelic et al., 2010) where the authors report on a significant increase of weight in a 20-year-long period. The studies in Western Europe (Cole, 2000) also report on a continual increase in weight, as reflected by the increasing childhood obesity epidemic. Alongside the secular changes in height, the corresponding changes in weight also take place, both in children and adults. This trend is the result of height increase and body changes caused by exceeded weight. The secular trend in weight is a combination of secular trend of height and obesity (Cole, 2003). Although the present study points to a certain increase in height, the BMI values reflect its decrease, and this is particulrly observable in girls. This trend has probably contributed to the absence of the secular trend of weight.

The body mass index (BMI kg/ $\mathrm{m}^{2}$ ) is the most commonly used indicator of nutritional status, as it can accurately assess the ideal weight in relation to the height. The childhood obesity epidemic is believed to have started in the 1980 (Cole, 2003) and since then it has spread rapidly. In relation to the reference values set for seven-year olds by Cole (2000), the BMI means of the children in Beocin municipality show normal nutritional status in the largest number of childen in all ten years of investigation. In comparison with the BMI of children in Vojvodina (Rakic), where the reported values were $17.47 \mathrm{~kg} / \mathrm{m}^{2}$ in boys and $16.94 \mathrm{~kg} / \mathrm{m}^{2}$ in girls, the children in this study show lower values. The values are also lower when compared with the results gathered in Jagodina (Pavlica et al.), as the reported BMI was $16.73 \mathrm{~kg} / \mathrm{m}^{2}$ in boys and $17.21 \mathrm{~kg} / \mathrm{m}^{2}$ in girls. In a 
transversal study conducted in two periods of time (2001-2004 and 2011-2014) including 8965 children aged 7-19 that lived in the urban areas of Vojvodina and Serbia (Rakic et al., 2016), the BMI of seven-year olds was significantly higher than the results of the present study. The results in the referred study were $17.31 \mathrm{~kg} / \mathrm{m}^{2}(2001-2004)$ and $16.49 \mathrm{~kg} / \mathrm{m}^{2}(2011-2014)$ in seven-year-old boys, and $16.85 \mathrm{~kg} / \mathrm{m}^{2}(2001-2004)$ and $17.23 \mathrm{~kg} / \mathrm{m}^{2}(2011-2014)$ in girls.

There are no significant differences in the BMI values regarding the two sexes, which is in line with the results reported in Serbia (Rakic; Djuraskovic et al.) and worldwide (Hurbo, 2008; Padez et al.; Saygin, 2014). In the period of ten years a considerable decrease of BMI has been recorded, in boys it is by $-1,04 \mathrm{~kg} / \mathrm{m}^{2}$, and in girls by $-0,85 \mathrm{~kg} / \mathrm{m}^{2}$.

Most of the subjects in this study are with normal nutritional status (63\%). Underweight is observed in $23 \%$ of children, while overweight and obesity appear in $10.1 \%$ and $3.65 \%$ of cases, respectively. A recent study of childhood and adolescence overweight and obesity in the period 2001-2004 and 2011-2014 in Serbia (Rakic et al.), based on IOTF criteria, reports on a significantly higher overweight in seven-yearold boys $(21.1 \%$; $17.6 \%)$ and girls $(19.4 \% ; 19.6 \%)$ than this is the case in the present study. The same holds good for obesity, as the reported values in the two periods were $12.1 \%$ and $7.8 \%$ in boys, and in girls $8.8 \%$ and $13.7 \%$. In the reported study (Rakic et al.), no significant differences were recorded in the prevalence of overweight and obesity. A similar conclusion can be drawn in the present study, as the results point to a considerable increase in the prevalence of underweight, while overweight and obesity prevalence have not shown any dramatic changes.
Analysing the period of ten years, the height, weight and BMI in seven-year-olds living on the territory on Beocin municipality have proven to be slightly lower than in the children of the same age in other parts of Vojvodina and Serbia. The study has pointed to an increasing trend in height and a decrease of BMI. The lower values of height, weight and BMI can be explained by the fact that a considerable number of the subjects are of Roma population. In all ten years of the investigation, the percentage of Roma boys ranges from 10.81 $\%$ (in 2005) to $25.45 \%$ (in 2012), and in girls, from $18.75 \%$ (in 2008) to $38.88 \%$ (in 2011). Previous research (Pavlica, 2009) has shown that Roma population is characterised by lower values of anthropological traits and BMI, which makes this ethnic group different from other nationalities living in Vojvodina. The Roma are the second largest ethnic group in Beocin municipality. According to the survey conducted from January to September 2014 that evaluated the standards of the Roma population, this ethnic group has proved to be the most vulnerable minority regarding all social parameters relevant for assessing the social status of a group or community (www.beocin.rs/sr/?p=left/StrateskaDokumenta). The present results are in line with findings reported in the last ten years in Serbia, as they all point to a stagnation of childhood overweight and obesity and an increase in underweight prevalence. One of the limitations of the present study is certainly the fact that it included only seven-year-old children. Nevertheless, the obtained results point to the need of further investigations of children living in this region in order to provide a better insight into the changes of the morphological parameters.

ACKNOWLEDGEMENTS: The authors would like to thank Health-care centre "Dr Dusan Savic - Doda in Beocin, who gave us permission to use their data in the present study.

PAVLICA, T.; RAKIC, R. \& S`IRONJIC, T. Cambios en las características morfológicas durante el período 2005 - 2014 en una muestra de niños serbios de 7 años de edad. Int. J. Morphol., 35(2):691-697, 2017.

RESUMEN: Las características morfológicas de los niños suelen implicar los procesos de crecimiento y desarrollo. La información sobre el crecimiento de los niños en altura y peso corporal se utiliza a menudo como el indicador de su salud y de su estado nutricional. Como los parámetros son cambiantes tanto temporalmente como espacialmente, es importante realizar una evaluación continua. El objetivo del estudio fue investigar los cambios en las características morfológicas en una muestra de niños serbios de 7 años en el período 2005-2014. Los datos se obtuvieron de la documentación médica registrada en el período 2005-2014 en el Centro de Atención de Salud "Dr Dusan Savic - Doda" en Beocin, situado en la region central de la provincia Vojvodina, al Noroeste de Serbia. La mayor parte de la población se compone de serbios $(69,7 \%)$ y el segundo grupo más grande son los romaníes (9\%) que llegaron a esta región en la década de 1990 como refugiados de Kosovo. Los participantes fueron clasificados en base a su edad decimal de 6,50 a 7,49 años. Se midió la estatura y el peso corporal y se establecieron las categorías de estado nutricional en relación con los valores de corte del índice de masa corporal (IMC) de 7 años de edad $\left(\mathrm{kg} / \mathrm{m}^{2}\right.$ ), según lo propuesto por IOTF International Obesity Task Force. El estudio ha señalado una tendencia creciente en altura y una disminución del IMC. Analizando el período de diez años, la altura, el peso y el IMC en niños de siete años que viven en el territorio del municipio de Beocin han demostrado ser ligeramente más bajos que en los niños de la misma edad en otras areas de Vojvodina y Serbia. Los resultados obtenidos apuntan a la necesidad de nuevas investigaciones de los niños que viven en esta región con el fin de proporcionar una mejor visión de los cambios en los parámetros morfológicos.

PALABRAS CLAVE: Altura; Peso; IMC; Tendencia secular ; Serbia. 


\section{REFERENCES}

al-Hazzaa, H. M. Anthropometric measurements of Saudi boys aged 6-14 years. Ann. Hum. Biol., 17(1):33-40, 1990.

Bharati P.; Itagi S. \& Megeri, S. N. Anthropometric measurements of school children of Raichur (Karnataka). J. Hum. Ecol., 18(3):177-9, 2005.

Ceylan, H. I.; Saygin, O. \& Irez, G. B. The Examining body composition, sprint and coordination characteristics of the children aged $7-12$ years. Anthropologist, 18(3):859-67, 2014.

Cole, T. J. Secular trends in growth. Proc. Nutr. Soc., 59(2):317-24, 2000.

Cole, T. J. The secular trend in human physical growth: a biological view. Econ. Hum. Biol., 1(2):161-8, 2003.

Cukic, M.; Vasic, B.; Jelenkovic, B. \& Cukic, M. Nutritional status of children before starting school in two generations of children born in 1994 and 2004. Timoc. Med. Glas., 37(3):134-8, 2012.

Djuraskovic, R.; Kostic, R.; Pantelic, S.; Zivkovic, D.; Uzunovic, S.; Purenovic, T. \& Zivkovic, M. A comparative analysis of the anthropometric parameters of seven-year-old children. Facta Univ. Ser. Phys. Educ. Sport, 7(1):79-90, 2009.

Herman-Giddens, M. E. Recent data on pubertal milestones in United States children: the secular trend toward earlier development. Int. J. Androl., 29(1):241-6, 2006.

Holm, I.; Fredriksen, P.; Fosdahl, M. \& Vøllestad, N. A normative sample of isotonic and isokinetic muscle strength measurements in children 7 to 12 years of age. Acta Paediatr, 97(5):602-7, 2008.

Hurbo, T. Secular changes in height, weight and chest circumference of 4 7 year old children from Minsk in the 20th century. Acta Med. Litu., 15(4):222-8, 2008.

Kaplowitz, P. Pubertal development in girls: secular trends. Curr. Opin. Obstet. Gynecol., 18(5):487-91, 2006.

Kromeyer-Hauschild, K. \& Jaeger, U. Growth studies in Jena, Germany: Changes in sitting height, biacromial and bicristal breadth in the past decenniums. Am. J. Hum. Biol., 12(5):646-54, 2000.

Kumar, R.; Bandyopadhyay, S.; Aggarwal, A. K. \& Khullar, M. Relation between birthweight and blood pressure among 7-8 year old rural children in India. Int. J. Epidemiol., 33(1):87-91, 2004.

Loesch, D. Z.; Stokes, K. \& Huggins, R. M. Secular trend in body height and weight of Australian children and adolescents. Am. J. Phys. Anthropol., 111(4):545-56, 2000.

Padez, C.; Fernandes, T.; Mourão, I.; Moreira, P. \& Rosado, V. Prevalence of overweight and obesity in 7-9-year-old Portuguese children: trends in body mass index from 1970-2002. Am. J. Hum. Biol., 16(6):670-8, 2004.

Pantelic, S.; Nikolic, M. \& Djuraskovic, R. Razvojne karakteristike sedmogodisnjih decaka iz razlic `itih vremenskih perioda. Glas. Antropol. Drus. Srb., (45):319-26, 2010.

Pavlica, T. Anthropological Characteristics of Adult Population in Banat and Backa. PhD Thesis. Novi Sad, University of Novi Sad - Faculty of Science - Department of Biology and Ecology. 2009. pp.198.

Pavlica, T.; Rakic, R.; Djuricanin, A.; Korovljev, D. \& Srdic, B. Growth and nutritional status of children and adolescents from 7 to 19 years of age in the town of Jagodina (Central Serbia). HealthMED, 6(1):28493, 2012.

Podstawski, R. \& Borysawski, K. Relationships between selected anthropometric features and motor abilities of children aged $7-9$. Clin. Kinesiol., 66(4):82-90, 2012.

Rakic, R. The Significance of some Environmental Factors on the Growth and Development of Children and Adolescents. PhD Thesis. Novi Sad, University of Novi Sad - Faculty of Science - Department of Biology and Ecology, 2009.

Rakic, R.; Pavlica, T. \& Jovicic, D. Overweight and obesity in children and adolescents from Serbia in the period 2001-2004 and 2011-2014. Anthropol. Anz., 73(2):109-16, 2016.

Saygin, O. Physical activity level and obesity prevalence of primary and secondary students. Anthropologist, 18(2):371-7, 2014.

Toselli, S.; Ventrella, A. R.; Franzaroli, G. \& Brasili, P. Growth and secular trend in school-children from Cento, Ferrara, Italy. Coll. Antropol., 30(1):65-74, 2006.

Zafirova, B. \& Todorovska, L. Anthropometric parameters of growth and nutritional status in children aged 6 to 7 years in R. Macedonia. $A d v$. Med. Sci., 54(2):289-95, 2009.

\author{
Correspoding author: \\ Dr. Tatjana Pavlica \\ University of Novi Sad \\ Department for Biology and Ecology \\ Novi Sad \\ SERBIA
}

Email: tatjana.pavlica@dbe.uns.ac.rs

Received: $20-10-2016$

Accepted: 16-03-2017 